\title{
PELAKSANAAN DAN PENGEMBANGAN WAKAF UANG DI INDONESIA
}

\author{
Diah Sulistyani, Nur Asikin, Soegianto Soegianto, Bambang Sadono \\ Magister Hukum Universitas Semarang, Semarang \\ diahmuladi@gmail.com
}

\begin{abstract}
Abstrak
Penelitian ini bertujuan untuk mengkaji dan menganalisis pengembangan wakaf uang ditinjau dari Undang-Undang Nomor 41 Tahun 2014 tentang Wakaf. Wakaf uang adalah salah satu bentuk wakaf yang baru di Indonesia, yang mana pengembangannya layak dilakukan terutama ketika perekonomian bangsa Indonesia sedang lemah. Metode pendekatan adalah yuridis normatif, sumber data adalah data sekunder, teknik pengumpulan data dilakukan melalui studi kepustakaan, dan teknik analisis data menggunakan analisis kualitatif. Hasil penelitian menunjukkan bahwa pengembangan wakaf uang dalam Undang-Undang Nomor 41 Tahun 2004 tentang Wakaf mencakup penghimpunan dana wakaf, pengelolaan wakaf uang dan pendistribusian hasil wakaf tunai. Kendala pengembangan wakaf uang sebagaimana diatur dalam Undang-Undang Nomor 41 Tahun 2004 tentang Wakaf adalah kurangnya pemahaman masyarakat mengenai wakaf uang dengan solusi BWI bersama pihak terkait dalam hal ini adalah LKS-PWU maupun Nazhir harus terus menyosialisasikan hukum wakaf tunai pada masyarakat; kurang profesionalnya Nazhir dalam pengelolaan wakaf uang solusinya adalah peningkatan kualitas nazhir agar profesional dan amanah dalam pengelolaan wakaf uang; kurangnya pemahaman dan kemampuan praktisi wakaf dalam pengembangan wakaf uang dengan solusi peningkatan kemampuan semua praktisi wakaf terlebih Nazhir sehingga mampu mengelola dan mengembangkan wakaf secara profesional dan amanah serta sinergitas sehingga pengelolaan dan pengembangan wakaf di Indonesia sukses.
\end{abstract}

\section{Kata kunci : Pengembangan; Wakaf Uang; Nazhir}




\title{
IMPLEMENTATION AND DEVELOPMENT OF MONEY WAKAF IN INDONESIA
}

\begin{abstract}
This study aims to examine and analyze the development of cash Wakaf in terms of Law Number 41 of 2014 concerning Wakaf. Money Wakaf is a new form of Wakaf in Indonesia, which development is feasible, especially when the Indonesian economy is weak. The approach method is juridical normative, the data source is secondary data, the data collection technique is done through library research, and the data analysis technique uses qualitative analysis. The results show that the development of Money Wakaf in Law Number 41 of 2004 concerning Wakaf includes the collection of Wakaf funds, management of Money Wakaf and distribution of Money Wakaf proceeds. The obstacle to developing Money Wakaf as regulated in Law Number 41 of 2004 concerning Wakaf is the lack of public understanding of Money Wakaf with BWI's solution with related parties, in this case LKS-PWU and Nazhir must continue to socialize Money Wakaf law to the public; Nazhir's lack of professionalism in managing Money Wakaf. The solution is to improve the quality of Nazhir so that it is professional and trustworthy in managing Money Wakaf; The lack of understanding and ability of Wakaf practitioners in the development of Money Wakaf with solutions to increase the capabilities of all Wakaf practitioners, especially Nazhir, so that they are able to manage and develop Wakaf in a professional and trustworthy manner and in synergy so that the management and development of Wakaf in Indonesia is successful.
\end{abstract}

Keywords: Development; Money Wakaf; Nazhir 


\section{A. PENDAhULUAN}

Wakaf merupakan salah satu dari amal jariyah yang diajarkan dalam hukum Islam dalam menyalurkan rezeki yang telah diberikan Allah kepada hambaNya. Wakaf sangat besar pahalanya mengingat manfaatnya yang dirasakan oleh banyak orang dan bersifat kekal. Wakaf tidak tersurat secara jelas dalam Al Qur'an, namun dalam beberapa ayat Al Qur'an menyiratkan anjuran untuk berwakaf, yang mana ayat-ayat tersebut selanjutnya digunakan oleh para ahli sebagai dasar hukum disyariatkannya wakaf. Salah satunya adalah sebagaimana dalam tertulis dalam QS. Al Baqarah ayat 267 yang menganjurkan kepada manusia untuk menafkahkan hartanya di jalan Allah.

Wakaf ditinjau dari bentuknya telah mengalami perkembangan, yang semula sebatas benda tak bergerak, kini berkembang sehingga benda bergerak pun bisa dijadikan sebagai benda wakaf misalnya saham atau uang. Wakaf di berbagai negara Islam misalnya Yordania, Mesir, Turki dan Saudi Arabia bisa berbentuk sarana/fasilitas ibadah serta pendidikan. Selain itu, wakaf dapat berbentuk tanah perkebunan, tanah pertanian, uang, saham, real estate dan sebagainya, dimana kesemuanya di kelola secara produktif. Pengelolaan wakaf yang produktif pada akhirnya akan dapat meningkatkan kesejahteraan masyarakat. ${ }^{1}$ Wakaf uang adalah salah satu bentuk wakaf yang baru di Indonesia. Meskipun demikian, di beberapa negara telah melakukan pengkajian dan pengembangan mengenai wakaf uang. Wakaf berupa uang sebenarnya sudah mulai ada sejak masa Mamluk, mengingat uang merupakan bentuk wakaf yang potensial dalam pengembangannya. Wakaf berupa uang di Indonesia diatur dalam Undang-Undang Nomor 41 Tahun 2004 tentang Wakaf (selanjutnya disebut UU Wakaf) yaitu pada Pasal 16, Pasal 28, Pasal 29, Pasal 30. Pasal 16 UU Wakaf menyebutkan bahwa harta benda wakaf terdiri dari benda tidak bergerak dan benda bergerak dimana benda bergerak adalah harta benda yang tidak bisa habis karena dikonsumsi, salah satunya adalah uang. Ketentuan Pasal 16 UU Wakaf tersebut diatas menunjukkan bahwa harta benda wakaf sudah mengalami perkembangan yang pesat, dimana seseorang untuk dapat berwakaf tidak harus menjadi kaya yang memiliki banyak tanah terlebih dahulu untuk diwakafkan.

${ }^{1}$ Badan Pengkajian Hukum Nasional, Laporan Akhir Tim Pengkajian Tentang Aspek Hukum Wakaf Uang, Jakarta, BPHN, 2009, hlm 2. 
Seseorang yang ingin berwakaf bisa menyisihkan sejumlah uang untuk berwakaf yang disebut sebagai wakaf uang atau wakaf tunai. ${ }^{2}$

Penelitian tentang wakaf uang ini terkait dengan penelitian Syarif Hidayatullah (2016) dengan judul "Wakaf Uang Dalam Perspektif Hukum Islam dan Hukum Positif di Indonesia", dalam penelitian tersebut mengangkat permasalahan bagaimanakah kedudukan hukum wakaf uang dan penerapannya dalam hukum islam dan hukum positif di Indonesia? Hasil dari penelitian tersebut Mejelis Ulama Indonesia (MUI) telah memfatwakan, bahwa wakaf uang diperbolehkan dengan syarat, bahwa wakaf uang hanya boleh disalurkan dan digunakan untuk hal-hal yang dibolehkan secara shar'i dan harus dijamin kelestariannya, dan wakaf uang sudah menjadi hukum positif di Indonesia karena telah ada undang-undang yaitu Undang-Undang Nomor 41 Tahun 2004 Tentang Wakaf pada pasal 16 ayat (1) Tentang wakaf benda bergerak. Juga telah ada Peraturan Pemerintah Nomor 42 Tahun 2006 Tentang pelaksanaannya pada pasal 15 sub c dan pada pasal 22 ayat (1) dan (2). ${ }^{3}$

Sedangkan Khadijah Hasim dkk (2016) dalam penelitiannya yang berjudul “Analisis Faktor-Faktor yang Memengaruhi Penghimpunan Wakaf Uang di Indonesia (Pendekatan Analytical Network Process)" lebih fokus mengkaji tentang faktor-faktor yang memengaruhi tingkat penghimpunan dibagi menjadi tiga aspek, yaitu kelembagaan, masyarakat, dan pemerintahan. Hasil prioritas menunjukkan bahwa aspek kelembagaan memiliki pengaruh paling besar terhadap tingkat penghimpunan wakaf uang dan tiga faktor yang paling berpengaruh adalah kefokusan lembaga nazhir, pemahaman masyarakat mengenai wakaf uang, dan kelengkapan perangkat hukum wakaf uang. ${ }^{4}$

Penelitian tentang wakaf uang oleh Muhammad Tho'in dan Iin Emy Prastiwi (2015) lebih fokus mengkaji wakaf uang dalam perspektif syariah. Dalam penelitiannya tersebut menjelaskan bahwa sistem wakaf merupakan konsep yang tidak secara jelas dan tegas disebutkan dalam Al Qurean, dan hadits. Pendapat ulama mengenai obyek wakaf memperlihatkan bahwa syarat-syarat benda wakaf (harus

${ }^{2}$ Sudirman Hasan, "Wakaf Uang dan Implementasinya di Indonesia", Jurnal De Jure, Jurnal Syariah dan Hukum 2 (2), 2010, hlm 163.

${ }^{3}$ Syarif Hidayatullah,"Wakaf Uang Dalam Perspektif Hukum Islam dan Hukum Positif di Indonesia”, Jurnal Salam 6 (1) 2016. http://dx.doi.org/10.15408/sjsbs.v3i1.3306

${ }^{4}$ Khadijah Hasim dkk, "Analisis Faktor-Faktor yang Memengaruhi Penghimpunan Wakaf Uang di Indonesia (Pendekatan Analytical Network Process) ”, Jurnal Al-Muzara'ah 4 (2), 2016.

https://doi.org/10.29244/jam.4.2.127-141 
benda, bermanfaat, tidak sekali pakai, tidak haram zatnya dan harus milik wakif secara sempurna). Wakaf tunai tidak didukung oleh hadis secara khusus, dan menggunakan ayat-ayat al-Qur' an dan hadis bersifat umum. Oleh karena itu, penentuan syarat-syarat obyek wakaf termasuk wilayah ijtihadi ${ }^{5}$

Penelitian ini berbeda dengan penelitian sebelumnya hal ini dapat dilihat dari penelitian oleh Syarif Hidayatullah yang hanya fokus mengkaji kedudukan hukum wakaf uang dalam perspektif hukum Islam dan hukum positif di Indonesia. Sedangkan pnelitian oleh Khadijah Hasim lebih fokus mengkaji tentang faktor-faktor yang memengaruhi tingkat penghimpunan dibagi menjadi tiga aspek, yaitu kelembagaan, masyarakat, dan pemerintahan. Penelitian oleh Muhammad Tho'in dan Iin Emy Prastiwi fokus mengkaji wakaf uang dalam perspektih syariah. Sedangkan penelitian ini mengkaji bagaimana pengembangan dan pelaksanaan wakaf uang di Indonesia serta bagaimana kendala dan solusinya. Tujuan dari penelitian ini mengkaji dan menganalisis pengembangan wakaf uang ditinjau dari Undang-Undang Nomor 41 Tahun 2014 tentang Wakaf.

\section{B. PERMASALAHAN}

1. Bagaimana pengembangan wakaf uang dalam Undang-Undang Nomor 41 Tahun 2004 tentang Wakaf?

2. Bagaimana kendala dan solusi pengembangan wakaf uang sebagaimana diatur dalam Undang-Undang Nomor 41 Tahun 2004 tentang Wakaf?

\section{METODE PENELITIAN}

Penelitian menggunakan metode pendekatan yuridis normatif, sehingga data yang digunakan data sekunder. Adapun teknik pengumpulan data dilakukan melalui studi kepustakaan sedangkan teknik analisis data menggunakan analisis kualitatif.

D. PEMBAHASAN

\section{Pengembangan Wakaf Uang Dalam Tinjauan Undang-Undang Nomor 41 Tahun 2004 Tentang Wakaf}

Pada awalnya, umat Islam sudah mengenal wakaf berupa tanah yang kemudian di atas tanah tersebut dibangun masjid, sekolah, pondok pesantren, rumah sakit dan sebagainya. Wakaf tersebut hanya dapat dimanfaatkan oleh masyarakat yang berada

${ }^{5}$ Muhammad Tho'in, Iin Emy Prastiwi, “Wakaf Uang Perspektif Syariah”, Jurnal Ilmiah Ekonomi Islam 1(2), 2015. http://dx.doi.org/10.29040/jiei.v1i02.29 
di wilayah lingkungan tersebut, sementara masyarakat miskin di Indonesia tersebar di berbagai daerah, sehingga perlu adanya pengembangan wakaf yang tidak hanya dalam bentuk benda tak bergerak saja. Seiring dengan adanya kebutuhan berupa dana untuk mengentaskan kemiskinan, maka timbul pemikiran untuk berwakaf dalam bentuk uang. Hal ini didasari bahwa uang mempunyai sifat yang fleksibel dan tidak mengenal batas pendistribusian. ${ }^{6}$

Di Indonesia, pengembangan wakaf tunai didasarkan pada UU Wakaf. Kelahiran Undang-Undang Nomor 41 Tahun 2004 tentang Wakaf pada prinsipnya mengatur masalah wakaf. Fungsi negara dalam mengatur atau mengundang-undangkan wakaf bukan mengintervensi wakaf, akan tetapi lebih pada upaya menjaga ketertiban dalam pelaksanaan wakaf agar berjalan sesuai orientasi yang seharusnya. Dalam proses dan sifat pengelolaan dan pengembangan tersebut, negara mengatur secara tegas, bahkan sifat-sifat negara memberikan unsur kekuatan berlakunya sanksi pidana yang diatur dalam ketentuan tersebut. ${ }^{7}$ Departemen Agama mendefinisikan wakaf uang sebagai wakaf yang dilaksanakan oleh seseorang, kelompok orang, dan lembaga atau badan hukum dalam bentuk uang. Wakaf uang atau wakaf tunai adalah salah satu bentuk wakaf yang diberikan kepada nadzir dalam bentuk uang tunai oleh wakif. ${ }^{8}$

Wakaf uang merupakan salah satu solusi untuk menjadikan wakaf lebih produktif. Wakaf uang yang dikelola dan diberdayakan oleh suatu lembaga secara profesional akan mampu memberikan kesejahteraan bagi masyarakat. ${ }^{9}$ Hal ini sejalan dengan istilah "menyejahterakan" yang tertuang dalam UU Wakaf yang diartikan sebagai upaya para pihak khususnya pengelola wakaf untuk meningkatkan kualitas hidup umat Islam melalui pemdayagunaan obyek wakaf. ${ }^{10}$

Pengelolaan wakaf uang hanya diatur oleh satu direktorat di bawah Kementerian Agama (selaku pengawas). Lembaga lain yang terkait dengan dengan pengelolaan wakaf uang adalah Badan Wakaf Indonesia BWI (selaku regulator sekaligus pengelola dana wakaf/nazhir), Nazhir (pengelola dana wakaf), dan Lembaga Keuangan Syariah

${ }^{6}$ M. Wahab Aziz, "Wakaf Tunai dalam Perspektif Hukum Islam”, International Journalllya 'Ulum Al-Din 9 (1), 2017, hlm. 3.

${ }^{7}$ Muhammad Junaidi, Abdullah Kelib, Diah Sulistiyani R.S, "Reposisi Peran Waqaf Dalam Pemberdayaan Ekonomi Islam Dalam Kajian Undang-Undang Nomor 41 Tahun 2004 Tentang Waqaf” Jurnal IUS 6(1), 2018, hlm. 63.

${ }^{8}$ Achmad Djunaidi, Strategi Pengembangan Wakaf Tunai di Indonesia, (Jakarta: Direktorat Pemberdayaan Zakat, Departemen Agama RI 2007). hlm.3.

${ }^{9}$ Fahmi Medias, "Wakaf Produktif dalam Perspektif Ekonomi Islam", Jurnal La Riba 4(1), 2010, hlm 69.

${ }^{10}$ Jaih Mubarok, Wakaf Produktif, (Bandung : Simbiosa Rekatama Media, 2008), hlm. 27. 
Penerima Wakaf Uang (LKS PWU, sebagai pihak yang menerima dan mengumpulkan dana wakaf). ${ }^{11}$

Ditinjau dari UU Wakaf, pengembangan wakaf uang dapat dijabarkan sebagai berikut:

1. Pembentukan institusi wakaf

Lahirnya UU Wakaf membawa konsekuensi bagi sistem pengelolaan wakaf di Indonesia agar lebih profesional dan independen. Untuk itu diperlukan suatu lembaga baru yang memiliki kapasitas dan kapabilitas dalam memberdayakan aset wakaf di Indonesia agar lebih produktif. Badan Wakaf Indonesia (BWI) merupakan jawaban bagi pengembangan pengelolaan perwakafan Indonesia dengan lebih profesional dan modern sehingga menghasilkan manfaat wakaf yang dapat mensejahterakan umat. Badan Wakaf Indonesia menduduki peran kunci, selain berfungsi sebagai nazhir, BWI juga akan sebagai pembina nazhir sehingga harta benda wakaf dapat dikelola dan dikembangkan secara produktif. ${ }^{12}$ Menurut UU Wakaf keanggotaan BWI diangkat dan diberhentikan oleh Presiden. Sedangkan pertanggungjawaban pelaksanaan tugas di lakukan oleh lembaga audit independen dan disampaikan kepada Menteri serta diumukan kepada masyarakat luas.

2. Penghimpunan wakaf uang

Penghimpunan dana diatur dalam Pasal 28 UU Wakaf jo Pasal 23 PP Nomor 41 Tahun 2006 yang menyatakan bahwa wakif dapat mewakafkan benda bergerak berupa uang melalui Lembaga Keuangan Syariah (LKS) yang ditunjuk oleh Menteri sebagai LKS Penerima Wakaf Uang (LKS PWU). Dalam hal ini LKSPWU juga bertugas untuk dengan memberitahukan kepada masyarakat statusnya sebagai LKS-PWU. Hal tersebut berdasarkan Pasal 25 PP No. 42 Tahun 2006.

3. Pengelolaan wakaf uang

Orientasi dalam mengelola dana wakaf adalah bagaimana pengelolaan tersebut mampu memberikan hasil yang semaksimal mungkin, sehingga dana-dana tersebut harus diinvestasikan pada usaha usaha produktif. Terdapat beberapa pilihan seperti investasi langsung pada bidang-bidang produktif, investasi melalui

${ }^{11}$ Kemenkeu, "Strategi Pengembangan Wakaf Uang dalam Rangka Pendalaman Pasar Keuangan Syariah" (https://fiskal.kemenkeu.go.id, diakses 11 Agustus 2020)

${ }_{12}$ Muhammad Aziz, "Peran Badan Wakaf Indonesia (BWI) Dalam Mengembangkan Prospek Wakaf

Uang Di Indonesia”, JES 1 (2), 2017, hlm 204. 
deposito pada bank Syariah, investasi penyertaan melalui perusahaan modal ventura, dan investasi portofolio lainnya dengan mempertimbangkan potensi hasil dan resikonya. ${ }^{13}$

Hal tersebut sebagaimana diamanatkan dalam Pasal 48 Peraturan Pemerintah Nomor 46 Tahun 2006 yang menjelaskan bahwa pengelolaan dan pengembangan atas harta benda wakaf uang hanya dapat dilakukan melalui investasi pada produkproduk LKS dan/atau instrument keuangan syariah. Pengelolaan dan pengembangan wakaf uang atas setoran wakaf uang dan investasi wakaf uang oleh Nazhir menurut ketentuan Pasal 9 ayat (5) Peraturan BWI No.1 Tahun 2009 wajib ditujukan untuk optimalisasi perolehan keuntungan dan/atau pemberdayaan ekonomi ummat. Sedangkan pengelolaan dan pengembangan wakaf uang atas hasil investasi wakaf uang oleh Nazhir wajib ditujukan untuk pemberdayaan ekonomi ummat dan/atau kegiatan-kegiatan sosial keagamaan.

Pasal 45 ayat (2) PP Wakaf menyebutkan bahwa "Dalam mengelola dan mengembangkan harta benda untuk memajukan kesejahteraan umum, nazhir dapat bekerjasama dengan pihak lain sesuai dengan prinsip syariah. Dengan demikian dapat dijelaskan bahwa dalam rangka memproduktifkan harta wakaf guna diambil hasilnya untuk mauquf alaih, Nazhir dapat bekerjasama dengan pihak manapun selama berdasarkan prinsip syariah. ${ }^{14}$

Sehingga peran lembaga Nazhir lebih terbuka dalam memberikan laporan terhadap kondisi dan perkembangan harta wakaf yang ada. Untuk itu, agar pengelolaan wakaf dapat lebih bisa dipertanggungjawabkan oleh lembaga Nazhir yang ada kepada pemerintah dan masyarakat umum. ${ }^{15}$

4. Pendistribusian dana hasil wakaf uang

Pendistribusian hasil wakaf tunai harus memperhatikan tujuannya, yaitu penyantunan, pemberdayaan, investasi sumber daya insani, maupun investasi infrastruktur. Hasil yang diperoleh tersebut juga sebagian porsi tertentu perlu dialokasikan untuk menambah besaran nilai awal wakaf tunai, dengan

\footnotetext{
${ }^{13}$ Kementrian Agama RI, Strategi Pengembangan Wakaf Tunai di Indonesia, Jakarta : Kementrian Agama RI, Direktorat Jenderal Bimbingan Masyarakat Islam, Direktorat Pemberdayaaan Wakaf, 2013, hlm. 15.

${ }^{14}$ Abdullah Ubaid, "Kemitraan Nazhir dengan Bank Syariah dalam Mengembangkan Wakaf Uang : Studi Perbandingan Di Indonesia, Bangladesh Dan Yordania", Jurnal Kuriositas 8 (1), 2015, hlm. 18.

${ }^{15}$ Lambang Prasetyo, "Kedudukan Hukum Pengambilalihan Tanah Wakaf Yang Batal Demi Hukum Untuk Dibagikan Sebagai Harta Warisan Dalam Kajian Undang-Undang No. 41 Tahun 2004 Tentang Wakaf”, Jurnal Ius Constituendum 2 (1), 2017, hlm 86. http://dx.doi.org/10.26623/jic.v2i1.545
} 
pertimbangan pokok untuk mengantisipasi penurunan nilai awal wakaf tunai dan meningkatkan kapasitas modal awal tersebut. Pemilihan tujuan distribusi hasil wakaf tergantung atas ketersediaan atau besar kecilnya hasil yang dapat diperoleh dalam pengelolaan dana wakaf tunai. ${ }^{16}$

Pengembangan wakaf uang sebagaimana diatur dalam UU Wakaf telah memberikan maslahah bagi masyarakat. Wakaf uang harus dikembangkan, untuk dapat diambil manfaatnya. Hasil pengelolaan dana wakaf tunai dapat dimanfaatkan secara lebih luas dalam rangka kesejahteraan masyarakat banyak. Pengembangan wakaf uang termasuk dalam kategori mashlahah dharuriyah,yaitu kemaslahatan yang sangat dibutuhkan dalam kehidupan manusia di dunia dan di akhirat. ${ }^{17}$ Kemaslahatan wakaf dalam hal ini berkaitan dengan kebutuhan pokok yaitu memelihara agama, memilihara jiwa, memelihara harta. Dengan berwakaf, maka seseorang telah memelihara hartanya untuk dapat dimanfaatkan bagi sesama umat sehingga memberikan maslahah bagi kehidupan manusia di dunia. Selain itu, dengan berwakaf maka seseorang telah memelihara agama dan jiwanya untuk memperoleh kebahagiaan akhirat, sebag wakaf merupakan amal jariyah yang mana pahalanya akan terus mengalir meskipun orang yang berwakaf (wakif) tersebut telah meninggal dunia.

Pengembangan wakaf uang di Indonesia merupakan terobosan baru dalam bidang wakaf. Pengembangan wakaf uang dilakuan dengan beragam inovasi dalam pengelolaannya. Dalam hal ini wakaf uang yang dikelola oleh nazhir akan diinvestasikan pada berbagai bidang usaha sesusai syariah sehingga memperoleh keuntungan. Keuntungan tersebut yang kemudian diberikan kepada penerima manfaat dalam berbagai bidang seperti pendidikan, rumah sakit, UMKM, kegiatan sosial dan lain-lain.

Pada kenyataannya, "kontroversi dalam mekanisme wakaf uang tetap ada, yaitu mengenai sah tidaknya penggunaan danajjwakaf untuk investasi, karena logikanya beresiko jmusnah. Dana wakaf yang berupa uang apabila diinvestasikan, maka artinya dana wakaf akan tetap berbentuk uang, sedangkan uang tidak memiliki nilai intrinsik. Hal ini tidak bisa disamakan dengan peristiwa wakaf uang pada zaman dulu, dimana

${ }_{16}$ Muhyar Fanani, "Berwakaf Tak Harus Kaya Dinamika Pengelolaan Wakaf Uang di Indonesia”, Semarang, Walisongo Press, 2010, hlm. 16.

${ }^{17}$ Efrinaldi, "Rekonstruksi Teori Kemaslahatan dalam Wacana Pembaharuan Hukum Islam Telaah Kritis Pemikiran Najm Din Thufi”, (http://efrinaldi.wordpress.com, diakses 10 Desember 2019). 
e-ISSN : 2621-4105

uang yang dijadikan benda wakaf terbuat dari emass dan pperak. Dengan demikian, pelaksanaan wakaf uang yang terjadi pada zaman sekarang beresiko akan teredusinya nilai uang karena inflasi. Selain itu mekanisme dalam berinvestasi juga beresiko untuk terjadinya pelanggaran kaidah syariat. Pengembangan wakaf uang juga beresiko akan terjadinya nilai harta benda wakaf berkurang atau bahkan hilang. Kemungkinan resiko berkurang atau hilangnya nilai wakaf terjadi karena kemungkinan usaha yang dibiayai oleh dana wakaf mengalami kerugian, adanya risiko karena force majeur (bencana, kebakaran dan sebagainya), ataupun resiko yang disebabkan oleh ketidak profesionalan nadzir dalam mengelola wakaf produktif. ${ }^{18,}$

\section{Kendala Serta Solusi Pengembangan Wakaf Uang Sebagaimana Diatur dalam} Undang-Undang Nomor 41 Tahun 2004 tentang Wakaf

Potensi wakaf uang sangat besar untuk meningkatkan kesejahteraan masyarakat, namun demikian terdapat beberapa kendala dalam pengembangan wakaf uang untuk pengelolaan wakaf di Indonesia. Adapun kendala-kendala tersebut antara lain :

1. Kurangnya pemahaman masyarakat mengenai wakaf uang

Masyarakat pada umumnya masih beranggapan bahwa wakaf berupa harta tetap atau tidak habis pakai. Hal ini menjadi kendala sosialisasi hukum wakaf tunai khususnya di perdesaan. Hal ini sebagiamana dikemukakan oleh Ketua Divisi Humas, Sosialisasi, dan Literasi (Husoli) BWI Atabik Luthfi yang menyatakan bahwa masyarakat masih beranggapan wakaf adalah harta tak bergerak, wakaf itu tanah, masjid, kuburan. Wakaf uang masih asing bagi masyarakat perdesaan. Hal itu tidak lain lantaran wakaf masih dianggap sebagai barang tak bergerak. Padahal, perkembangan zaman sudah berbeda dari masa Rasulullah SAW. ${ }^{19}$

Melihat perkembangan ekonomi dan kebutuhan, wakaf tak bergerak tetap harus memperhatikan kebutuhan masyarakat. Sebagai contoh benda memang bersifat kekal, tetapi jika terbengkalai sama saja tidak memberi manfaat pada umat. Dengan adanya wakaf uang, hasil pengelolaan wakaf uang dapat dimanfaatkan untuk mendayagunakan tanah wakaf yang terbengkalai tersebut.

\footnotetext{
${ }^{18}$ BPHN, Op.Cit., hlm 4.

${ }^{19}$ Umi Nur Fadhilah, Persepsi Jadi Kendala Sosialisasi Wakaf Tunai, https://www.republika.co.id, diakses 12 Agustus 2020.
} 
Solusi untuk mengatasi kendala tersebut adalah bahwa pihak BWI bersama pihak terkait dalam hal ini adalah LKS-PWU maupun nazhir harus terus menyosialisasikan hukum wakaf tunai dan manfaatnya pada masyarakat. Salah satu upaya yang sudah dilakukan yakni program wakaf goes to campus, wakaf goes to community atau wakaf goes to society. Dengan demikian, para tokoh agama di pedesaan lebih terbuka memandang hukum wakaf tunai.

2. Kurang profesionalnya nazhir dalam pengelolaan wakaf uang

Keberhasilan pengembangan wakaf uang banyak ditentukan oleh kemampuan nadzir yang profesional dan amanah dalam mengelola dan mengembangkan wakaf uang. Nazhir yang akan mengelola wakaf tunai pun tidak boleh asal-asalan karena menyangkut pengelolaan dana amanah umat. Persoalan profesionalisme nadzir masih menjadi kendala pengelolaan wakaf di Indonesia saat ini. Banyak nadzir di Indonesia yang tidak mempunyai kemampuan yang memadai, sehingga harta wakaf tidak berfungsi secara maksimal, bahkan tidak memberi manfaat sama sekali kepada sasaran wakaf.

Solusi untuk mengatasi hambatan terkait kelemahan nazhir adalah peningkatan kualitas nazhir. Nazhir tidak hanya harus memahami dan menghayati pengetahuan agama dan kebijakan negara untuk menahan diri agar tidak melakukan perbuatan yang dilarang agama dan Negara. Nazhir sebagai pemimpin usaha atau manajer bertugas berdasarkan perencanaan yang matang yang telah di susun sebelumnya dan mengaturnya agar perencanaan tersebut berjalan semestinya. Nazhir sebagai pelaksana, pengelola dan pengembang wakaf yang hanya berpikir tentang bagaimana supaya wakaf mendatangkan hasil yang sebesar-besarnya sesuai dengan syariah. ${ }^{20}$

Wakaf di Indonesia diarahkan sesuai kebijakan negara produktif untuk kepentingan ibadah dan memajukan kesejahteraan umum. Untuk bisa mencapainya, nazhir harus memahami dan menghayati pengetahuan agama dan kebijakan negara, juga memahami ilmu umum berbasis ekonomi dan bisnis profit oriented sesuai syariah, memiliki kemampuan entrepreneurship (nilai dan jiwa wirausaha); memiliki kepemimpinan yang diarahkan untuk mencapai tujuan-tujuan keuntungan, merancang visi dan strategi berdasarkan perhitungan pragmatis dan

\footnotetext{
${ }^{20}$ Badan Pengkajian Hukum Nasional, Op.Cit, hlm. 135.
} 
ekonomis perhitungan untung rugi; mempunyai prinsip tidak selalu bergantung pada modal tetapi bagaimana menciptakan sesuatu misalnya yang kering menjadi basah, yang tandus menjadi subur, yang tumbuh menjadi berkembang; berkemampuan mengajak orang lain mau bekerjasama berdasarkan perencanaan yang telah disesuaikan dan mengaturnya agar berjalan semestinya. Nazhir juga harus memiliki keterampilan melakukan analis pengambilan keputusan, berani mengambil resiko, mampu melihat dan menilai sebuah peluang yang terhampar di depannya, menciptakan kesempatan (opportunity creator), memiliki ide-ide baru yang orisinal (innovator), kemampuan beradaptasi, keterampilan teknologi informasi dan komunikasi, memiliki manajemen yang kuat, pemecahan masalah, serta berani menanggung resiko. ${ }^{21}$

Nazhir yang tidak memenuhi kualifikasi dan standar serta memahami ilmuilmu tersebut sesungguhnya sudah tidak relevan dengan tuntutan kemanjuan dan kebijakan negara yang telah membuka akses seluas-luasnya memajukan wakaf di Indonesia. Oleh karena itu, dan BWI yang mempunyai tugas dan fungsi (wewenang) melakukan pembinaan terhadap Nazhir dalam mengelola dan mengembangkan harta benda wakaf serta pemberhentian dan pengangkatan Nazhir harus bertindak dan berbuat konkrit menciptakan Nazhir yang profesional dan amanah.

3. Kurangnya kemampuan praktisi wakaf dalam pengembangan wakaf uang

Ada banyak unsur yang saling mempengaruhi dan menentukan suksesnya pengembangan wakaf uang di Indonesia, yaitu unsur pemerintah, unsur BWI, unsur LKS-PWU, unsur Wakif dan unsur Nazhir.Persoalan pengebangan wakaf uang di Indonesia sebenarya berada di sekitar praktisi wakaf sendiri yaitu Pemerintah, LKS-PWU, BWI, dan Nazhir. Para praktisi wakaf harus memiliki kemauan dan kemampuan menjalankan tugas dan fungsinya dengan baik, profesional dan amanah. Permasalahan tersebut bermuara pada dua hal, yaitu apakah praktisi wakaf di Indonesia telah memahami dan menyadari bahwa wakaf merupakan bagian dari ajaran Islam yang bernilai tinggi di dalamnya mengandung potensi ekonomi yang luar biasa besarnya yang dapat mensejahterakan umat, bangsa dan negara Indonesia? dan mampukah praktisi wakaf di Indonesia mengelola dan

${ }^{21}$ Ibid, hlm. 136. 
mengembangkan wakaf di Indonesia yang potensinya luar biasa yang dapat mensejahterakan umat, bangsa dan negara Indonesia tersebut ? Bila kedua pertanyaan tersebut dapat dijalankan oleh praktisi wakaf dengan baik, maka wakaf yang telah menjadi kebijakan negara mewujudkan potensi dan manfaat ekonomis harta benda wakaf untuk kepentingan ibadah dan/ atau kesejahteraan umum akan tercapai. Namun apabila praktisi wakaf di Indonesia tidak mampu menjalankan tugas dan fungsinya dengan baik, maka tujuan kebijakan wakaf tidak akan tercapai.

Pada konteks wakaf uang di Indonesia saat ini, bahwa hambatan utama pembangunannya bukan lagi pada image wakaf di Indonesia umumnya umat Islam berwakaf secara tradisional/konvensional tetapi terletak pada praktisi wakaf termasuk negara sebenarnya kurang dan tidak cepat beradaptasi membuat kebijakan wakaf sesuai dengan tuntutan kemajuan. ${ }^{22}$

Solusi untuk mengatasi hambatan tersebut adalah bahwa semua praktisi wakaf harus membekali diri dengan pengetahuan mengenai wakaf uang. Kedepannya, untuk kesuksesan dalam pengelolaan dan pengembangan wakaf uang di Indonesia, maka semua praktisi wakaf terlebih Nazhir harus mampu mengelola dan mengembangkan wakaf secara profesional dan amanah serta sinergitas, sehingga pengelolaan dan pengembangan wakaf di Indonesia sukses. Tidak sulit merubah pandangan masyarakat tentang wakaf uang asalkan masyarakat diberikan penjelasan yang dapat mengetuk hati dan pikiran bahwa berwakaf tidak hanya benda tidak bergerak tanah seperti masjid, langgar, musolla, madrasah, rumah yatim piatu, kuburan dan lain sebagainya, tetapi juga wakaf benda bergerak seperti uang, logam mulia, surat berharga, HAKI, hak sewa, kendaraan dan lain sebagainya dimana nilai pahalanya sama, maka umat Islam akan mengikutinya.

\section{E. PENUTUP}

Pengembangan wakaf uang dalam Undang-Undang Nomor 41 Tahun 2004 tentang Wakaf mencakup pembentukan institusi wakaf uang, penghimpunan dana wakaf, pengelolaan wakaf uang dan pendistribusian hasil wakaf tunai. Dalam hal ini wakif (pewakaf) menyalurkan sejumlah uang tertentu kepada LKS-PWU, yang kemudian diserahkan kepada nazhir untuk dikelola atau dijadikan aset produktif dengan cara dibelikan aset tetap yang bisa diperuntukkan manfaatnya untuk penerima

${ }^{22}$ Ibid, hlm. 137. 
e-ISSN : 2621-4105

wakaf atau diinvestasikan melalui usaha-usaha sesuai syariah dengan tingkat risiko terkendali, seperti deposito di bank syariah atuapun lembaga keuangan lainnya, sehingga pokoknya tetap. Hasil pengelolaan wakaf uang tersebut selanjutnya disalurkan untuk kepentingan kepentingan sosial yang menyeluruh, seperti bidang pendidikan, kesehatan, pelayanan sosial, maupun pengembangan ekonomi melalui pemberdayaan usaha kecil dan menengah. Pengembangan wakaf uang yang demikian dapat memberikan nilai kemanfaatan bagi kesejahteraan masyarakat. Kendala dan solusi pengembangan wakaf uang sebagaimana diatur dalam Undang-Undang Nomor 41 Tahun 2004 tentang Wakaf uang adalah kurangnya pemahaman masyarakat mengenai wakaf uang, solusinya adalah BWI bersama pihak terkait dalam hal ini adalah LKS-PWU maupun nazhir harus terus menyosialisasikan hukum wakaf tunai dan manfaatnya pada masyarakat. Kendala lainnya adalah kurang profesionalnya nazhir dalam pengelolaan wakaf uang, solusinya adalah peningkatan kualitas nazhir agar profesional dan amanah dalam pengelolaan wakaf uang. Kurangnya pemahaman dan kemampuan praktisi wakaf dalam pengembangan wakaf uang, solusinya adalah peningkatan kemampuan semua praktisi wakaf terlebih Nazhir sehingga mampu mengelola dan mengembangkan wakaf secara profesional dan amanah serta sinergitas, sehingga pengelolaan dan pengembangan wakaf di Indonesia sukses.

\section{DAFTAR PUSTAKA}

\section{Buku}

Achmad Djunaidi, Strategi Pengembangan Wakaf Tunai di Indonesia, Jakarta: Direktorat Pemberdayaan Zakat, Departemen Agama RI, 2007.

Badan Pengkajian Hukum Nasional, Laporan Akhir Tim Pengkajian Tentang Aspek Hukum Wakaf Uang, Jakarta : BPHN, 2009.

Jaih Mubarok, Wakaf Produktif, Bandung : Simbiosa Rekatama Media, 2008.

Kementrian Agama RI, Strategi Pengembangan Wakaf Tunai di Indonesia, (Jakarta : Kementrian Agama RI, Direktorat Jenderal Bimbingan Masyarakat Islam, Direktorat Pemberdayaaan Wakaf, 2013.

Muhyar Fanani, Berwakaf Tak Harus Kaya Dinamika Pengelolaan Wakaf Uang di Indonesia, Semarang: Walisongo Press, 2010. 
e-ISSN : 2621-4105

\section{Jurnal}

Abdullah Ubaid, "Kemitraan Nazhir dengan Bank Syariah dalam Mengembangkan Wakaf Uang : Studi Perbandingan Di Indonesia, Bangladesh Dan Yordania", Jurnal Kuriositas 8 (1), 2015. https://doi.org/10.35905/kur.v8i1.143

Fahmi Medias, "Wakaf Produktif dalam Perspektif Ekonomi Islam”, Jurnal La Riba 4 (1), 2010. DOI : $\underline{10.20885 / \text { lariba.vol4.iss1.art5 }}$

Khadijah Hasim dkk, "Analisis Faktor-Faktor yang Memengaruhi Penghimpunan Wakaf Uang di Indonesia (Pendekatan Analytical Network Process)” Jurnal Al-Muzara'ah Vol.4 No.2, 2016. https://doi.org/10.29244/jam.4.2.127-141

Lambang Prasetyo, "Kedudukan Hukum Pengambilalihan Tanah Wakaf Yang Batal Demi Hukum Untuk Dibagikan Sebagai Harta Warisan Dalam Kajian Undang-Undang No. 41 Tahun 2004 Tentang Wakaf", Jurnal Ius Constituendum 2(1), 2017. http://dx.doi.org/10.26623/jic.v2i1.545

Muhammad Aziz, "Peran Badan Wakaf Indonesia (BWI) Dalam Mengembangkan Prospek Wakaf Uang Di Indonesia", JES 2 (1), 2017.

Muhammad Junaidi, Abdullah Kelib, Diah Sulistyani R.S, "Reposisi Peran Waqaf Dalam Pemberdayaan Ekonomi Islam Dalam Kajian Undang-Undang Nomor 41 Tahun 2004 Tentang Waqaf” Jurnal IUS 6 (1), 2018.

Muhammad Tho'in, Iin Emy Prastiwi, "Wakaf Uang Perspektif Syariah”, Jurnal Ilmiah Ekonomi Islam 1 (2), 2015. http://dx.doi.org/10.29040/jiei.v1i02.29

M. Wahab Aziz, “Wakaf Tunai dalam Perspektif Hukum Islam”, International JournalIlya 'Ulum Al-Din 9 (1), 2017. DOI : 10.21580/ihya.18.1.1740

Syarif Hidayatullah, "Wakaf Uang Dalam Perspektif Hukum Islam dan Hukum Positif di Indonesia (Endowments Money in Perspective Islamic Law and Indonesian Law)" Salam L Jurnal Sosial dan Budaya Syar-i 3 (1), 2006.

Sudirman Hasan, Wakaf Uang dan Implementasinya di Indonesia, De Jure, Jurnal Syariah dan Hukum 2 (2), 2010.

\section{Peraturan perundang-undangan}

Undang-Undang Nomor 41 Tahun 2004 tentang Wakaf, Jakarta, 2004.

Peraturan Pemerintah Nomor 25 Tahun 2018 tentang Perubahan Atas Peraturan Pemerintah Nomor 42 Tahun 2006 tentang Pelaksanaan Undang-Undang Nomor 41 Tahun 2004 tentang Wakaf

Fatwa Majelis Ulama Indonesia Tahun 2002 tentang Wakaf Uang

Peraturan Badan Wakaf Indonesia (BWI) Nomor 01 Tahun 2009 tentang Pedoman Pengelolaan Dan Pengembangan Harta Benda Wakaf Bergerak Berupa Uang

\section{Website}

Efrinaldi, "Rekonstruksi Teori Kemaslahatan dalam Wacana Pembaharuan Hukum Islam Telaah Kritis Pemikiran Najm Din Thufi”, (http://efrinaldi.wordpress.com, diakses 10 Desember 2019).

Kemenkeu, "Strategi Pengembangan Wakaf Uang dalam Rangka Pendalaman Pasar Keuangan Syariah" (https://fiskal.kemenkeu.go.id, diakses 11 Agustus 2020) 
Diah Sulistyani, Nur Asikin, Soegianto Soegianto, Bambang Sadono

e-ISSN : 2621-4105

Umi Nur Fadhilah, Persepsi Jadi Kendala Sosialisasi Wakaf Tunai, https://www.republika.co.id, diakses 12 Agustus 2020. 